NBER WORKING PAPER SERIES

\title{
FREE TRADE, GROWTH, AND \\ CONVERGENCE
}

Dan Ben-David

Michael B. Loewy

Working Paper 6095

\section{NATIONAL BUREAU OF ECONOMIC RESEARCH 1050 Massachusetts Avenue \\ Cambridge, MA 02138 July 1997}

This paper is part of NBER's research program in International Trade and Investment. Any opinions expressed are those of the authors and not those of the National Bureau of Economic Research.

(C) 1997 by Dan Ben-David and Michael B. Loewy. All rights reserved. Short sections of text, not to exceed two paragraphs, may be quoted without explicit permission provided that full credit, including $\mathbb{C}$ notice, is given to the source. 
Free Trade, Growth, and Convergence

Dan Ben-David and Michael B. Loewy

NBER Working Paper No. 6095

July 1997

JEL Nos. E1, F1, O4

International Trade and Investment

\section{ABSTRACT}

What is the impact on output of movement towards free trade? Can trade liberalization have a permanent effect on output levels, and more importantly, does it have an impact on steady-state growth rates? The model developed here emphasizes the role that knowledge spillovers emanating from heightened trade can have in income convergence and growth rates over the long run. The model also facilitates an analysis of the dynamic behavior of income levels and terms of trade - as well as growth rates - during the transition between steady states. Among the results of the model, unilateral liberalization by one country induces a level effect on the liberalizing country that reduces the income gap between it and other wealthier countries. In some cases, the liberalizing country may even leapfrog over initially wealthier countries. From the long-run growth perspective, unilateral (and multilateral) liberalization generates a positive impact on the steady-state growth of all the trading countries.

Dan Ben-David

Berglas School of Economics

Tel Aviv University

Ramat-Aviv, Tel-Aviv 69978

ISRAEL and NBER

BenDavid@econ.tau.ac.il
Michael B. Loewy

Department of Economics

University of Houston

Houston, TX 77204-5882

MLoewy@uh.edu 


\section{INTRODUCTION}

There has been much discussion in recent years concerning the presumed advantages and disadvantages of enacting trade agreements designed to permit freer trade among countries. NAFTA and the Uruguay Round of GATT have been two of the main focal points of these discussions. At the core of these debates are the related questions of whether movement towards free trade will (a) foster a reduction in the disparity of incomes among countries and (b) will lead to more rapid growth for all parties concerned or just for a subset of the signatories.

With regard to the first question, it is not at all obvious why free trade should foster income convergence. From the international trade literature, the Factor Price Equalization Theorem (Samuelson, 1948; Helpman and Krugman, 1985) implies that if a number of limiting restrictions are met, then free trade in goods should lead to commodity price equalization and to a subsequent equalization of factor prices. However, as Rassekh and Thompson (1996) and Slaughter (1997) point out, factor price equalization need not be synonymous with an equalization of per capita incomes. From the traditional growth literature, the Solow (1956) model, and the Cass (1965) and Koopmans (1965) modifications, imply that differences in initial capital-labor endowments will be eliminated over time and that this in turn leads to a convergence in per capita incomes. But the Solow-Cass-Koopmans model focuses on a closed economy so that convergence occurs without the need for trade.

While the traditional trade and growth literature does not yield an unequivocal theoretical link between movement towards free trade and income convergence among countries, the empirical evidence suggests that there does indeed exist such a link. Studies by Ben-David $(1993,1994,1996)$ show that the elimination of trade barriers and increases in the volume of trade lead to a marked reduction in the income gaps that had existed between trading countries. Hence, one of the objectives of this paper is to develop an open-economy model that addresses the trade-convergence link.

With regard to the second question posed above, although a reduction in income disparity may 
be a desired result for some, it does not allay the concern of others that the income convergence may come at the expense of wealthier countries. To this end, the model also addresses the long-run growth implications of trade liberalization by endogenizing the steady-state impact of tariff reductions. The emphasis here is on developing as simple a model as possible in order to facilitate an analysis of levels in addition to just growth rates, and of transitional periods in addition to just steady states.

While most of the existing growth literature focuses on only two countries, or trading blocks, the model developed below - while deliberately rudimentary for the reasons outlined above - is a multicountry model that lends itself to analyses of trade agreements by subsets of countries. Unilateral trade liberalization, or multilateral liberalization for that matter, is shown to lead to terms of trade dynamics that result in both trade-creating and trade-diverting behavior during the transition and subsequent steady state. This trade-varying behavior ultimately affects in different ways both the output levels and the growth rates of the individual countries. Hence, an analysis that accounts for the price and trade dynamics makes it possible to determine the circumstances under which a fast growing country is in the process of catching up to the leaders or in the process of pulling away from the laggards. It also makes it possible to gauge the impact of unilateral, bilateral, or multilateral trade liberalization programs on the long-run growth rates of countries, be those countries directly or indirectly related to the particular liberalization programs.

The general equilibrium model presented here is based on the premises that (a) knowledge may be characterized as a non-rivalrous public good which in many cases is non-excludable and (b) that trade flows facilitate the diffusion of knowledge among countries. The non-rival aspect implies that ideas may be used concurrently in different places and on different production processes. Non-excludability implies that an idea has public good characteristics that limit the ability of its originators to receive compensation for its creation.

Heightened trade will, in general, lead to greater diffusion and faster knowledge growth and hence, to faster per capita output growth. Even though the liberalizing country's tariff reductions also 
affect relative prices which lead to reductions in trade between other pairs of countries, we show that the overall outcome of tariff elimination, even when it is being carried out by a single country, nevertheless leads to faster steady-state growth for all trading countries. This growth effect is greater the more countries enact tariff-reduction policies.

While all countries experience faster steady-state growth as a result of unilateral tariff reductions, the level effect for the liberalizing country is not negligible, enabling it to converge with, or even to leapfrog over other countries during the transition to the new steady state. Since all countries with similar levels of technology grow at the same rate in steady state (in lieu of any additional changes in commercial policy), the relative improvement of one country vis-a-vis the other countries will persist in the long-run.

At this juncture, it is important to clarify the boundaries of this paper and to specify its limitations. First, the framework developed here is obviously not the only way to characterize international trade's impact on economic growth. In order to focus on the impact of knowledge spillovers, some of the more traditional explanations (such as economies of scale and comparative advantage, as well as sectoral delineations of economies that include R\&D sectors) have been omitted. Second, this paper does not attempt to explain why countries levy tariffs in the first place nor why they continue to impede trade when this may inhibit growth. Trade barriers may exist as a result of uncertainty regarding the possible level and growth implications of liberalization. Alternatively, political economy considerations, which may differ across countries depending on the distribution of influence of various groups or factions, can lead to varying degrees of protection. In any event, this paper is not about why trade barriers exist, but about what may happen to output when they are removed.

The outline of the paper is as follows. The next section provides some background and discusses related studies. Section 3 provides a theoretical framework that details the contribution of trade towards the diffusion of knowledge while Section 4 describes the model's solution. The impact of tariff reductions on output levels and growth rates in the short and long runs is highlighted by means of 
numerical simulations in Section 5. Among other things, these simulations make it possible to examine what occurs during the transition between one steady state and another as a result of changes in tariff policies. Section 6 concludes.

\section{BACKGROUND AND MOTIVATION}

The past decade has been witness to a growing number of studies aimed at explaining the impact of international trade on economic growth. The main catalyst for the resurgence of this topic has been the emergence of growth models that endogenize the growth process, and in so doing, have created frameworks that enable an analysis of the growth effects of a host of policy instruments.

This resurgence notwithstanding, the relationship between trade and growth has been studied at least as early as Adam Smith. More recently, in the aftermath of World War II, economic policies were affected by two major (and contradictory) strands of influence. On the one hand, American policy makers exerted tremendous pressure on European countries to liberalize trade by making economic support via the Marshall Plan contingent on trade reform. On the other hand, import substitution policies, particularly for developing countries, received a boost from early work by Prebisch (1950), Singer (1950), Myrdal (1957, 1959) and others. Specifically, this work was interpreted as implying that the impact of terms of trade will be negative for developing countries that primarily produce goods with low income elasticities and that infant industries need increased protection in order to become viable. The latter view received support from several important international lending institutions which in turn led many poor countries to adopt more protectionist policies.

Over time, however, these protectionist views were challenged by increasing evidence that more outward-oriented economies seemed to be growing faster than countries that restricted trade. This observation received a variety of possible explanations by, among others, Kindleberger (1962), Caves (1965), Corden (1971), and Johnson (1971) who placed an emphasis on, respectively: the existence of a trade sector as a leading, balancing, or lagging sector; exports as a "vent for surplus"; "factor-weight" 
effects; and factor price and factor utilization ratios. More recent studies, which include Romer (1990, 1994), Feenstra (1996), Jones and Manuelli (1990), Grossman and Helpman (1991a, 1991b), Rivera-Batiz and Romer (1991a, 1991b), Stokey (1991), Young (1991), Backus, Kehoe, and Kehoe (1992), Baldwin (1992), Ruffin (1993), and Easterly, King, Levine, and Rebelo (1994) emphasize various other aspects of the growth process and how international trade may affect them.

But as Rodrik (1992) asks, if the positive link between trade and growth is so obvious, then why has it taken so long for the countries of the world to embrace free trade? Part of the answer lies in the fact that this positive relationship has not been particularly obvious. According to Olson (1982), the political and economic reorganizations that occurred following World War II led to the dissolution of many of the distributional coalitions that had previously existed. These developments were important aspects of the recovery process which culminated in, among other things, an eventual opening of markets. It is interesting to note that, while the postwar period has been characterized by movement towards freer trade, most countries experienced either growth slowdowns, or no noticeable growth improvements. $^{2}$

For example, Ben-David and Papell (1995a) study the behavior of GDP for 74 countries from 1950 through 1990 and show that 46 of the countries exhibit a break in their growth path during this period. Of these 46 countries, 41 experienced significant slowdowns following their breaks. Only five countries out of the entire sample exhibited significant increases in their rates of growth. From the trade perspective, however, Ben-David and Papell (1996) find that the majority of countries in the postwar period exhibited increases in the volume of their trade. The evidence of heightened trade on the one hand, combined with growth slowdowns on the other, appears to indicate that the relationship between trade and growth, to the extent that one exists, is a negative one (see also Fieleke, 1994).

\footnotetext{
' It should be pointed out that the postwar period has also been characterized by declining transportation costs that supplement the greater mobility of goods brought about the systematic removal of barriers to trade.

2 These slowdowns are examined in, among others: Griliches (1980), Bruno (1984), Romer (1987), Baumol, Blackman, and Wolff (1989), and De Long and Summers (1992).
} 
We claim that this is not the only way to interpret the empirical evidence, however. The postwar period is, by definition, a period following a major upheaval. Standard growth theory tells us that in the aftermath of a negative shock as great as World War II, countries should be expected to exhibit growth rates that initially exceed their steady-state rates. Eventually, as countries return to their original growth paths, their growth rates should fall back to the original steady-state values. Hence, the fact that growth rates have fallen during the past several decades could very well be due to the return of countries to their long-run growth paths. However, in light of the extensive trade liberalization that has occurred since the war, one might ask whether postwar steady-state paths are the same as the prewar paths or are they new paths characterized by faster growth?

Ben-David and Papell (1995b) examine 12 decades of annual GDP data for fifteen OECD countries. Each of these countries was found to have experienced a significant break in their real per capita GDP between 1870 and 1989 . In all but one of the cases, the break was characterized by a sharp drop in levels followed by substantially faster growth. ${ }^{3}$ For the majority of the countries, the break occurred during World War II. ${ }^{4}$ While the standard neoclassical model predicts that the countries should have returned to their earlier steady-state paths after an interim transition period, Ben-David and Papell show instead that each of the countries in the sample rebounded to a new path that transcended its old one. Not only were output levels higher along the new path, but average growth rates for the period after the old paths were surpassed were found to be two and a half times higher than the prebreak steady-state growth rates.

An interesting case in point is that of the founding members of the European Economic Community (EEC). The removal of trade barriers between these countries led to substantial increases in trade, with the average ratio of exports to GDP in five of the six original member countries (Belgium, France, Germany, Italy, and the Netherlands) during the postwar years exceeding the average ratio for

\footnotetext{
${ }^{3}$ The other country, Switzerland, experienced a positive increase in GDP levels.

${ }^{4}$ World War I and the Great Depression were the primary break periods for the remaining countries.
} 
these countries in the seven decades preceding World War II by a factor of 2.11.5 Although the increased openness of the postwar period is accompanied by higher growth rates, it would be presumptuous to attribute all of the faster growth following World War II to increased trade. Nevertheless, it is still useful to compare results between the relatively free trade years prior to World War I (1870-1913) and the years following the postwar slowdown (1973-1989). The average exportoutput ratio across the five countries for the post-slowdown period exceeds the pre-World War I ratio by a factor of 2.83. Likewise, the five country average growth rate of per capita real GDP for the postslowdown period is higher as well, exceeding the pre-World War I rate by a factor of 1.63 . Not only did the EEC countries grow faster, the degree of income disparity among them declined significantly as well. ${ }^{6}$ How might trade have played a role in the heightened growth and the income convergence that occurred?

The notion that the dissemination of ideas is essential to the growth process would seem to be fairly intuitive. Hence, any mechanism which might advance the flow of knowledge from one country to the next should provide a positive, or in the least, a non-negative spur to the development of countries. Parente and Prescott (1994) show how differences in barriers to technology adoption can account for the large income gaps across countries while Rosenberg (1980) provides evidence that the increasing number of ideas has been an important factor in raising modern standards of living. ${ }^{7}$

What spurs the diffusion of these ideas? The primary assumption of this paper, which follows the intuition of Dollar, Wolff, and Baumol (1988), Grossman and Helpman (1991a, 1991b, 1995), and others is that trade between countries acts as a conduit for the dissemination of knowledge. ${ }^{8}$ Therefore,

\footnotetext{
5 The periods of comparison here are 1870-1939 and 1950-89 using data from Maddison (1991). The sixth original member of the EEC, Luxembourg, is not included in Maddison's data set.

${ }^{6}$ See Ben-David (1993, 1994).

${ }^{7}$ Eaton and Kortum (1994) show that the number of patents registered abroad - as an indicator of the development of ideas affects the international diffusion of technology.

${ }^{8}$ Marin (1995) provides empirical evidence showing that Austria's relatively fast growth during the postwar period "has been induced by knowledge spillovers from its trading partners," particularly Germany.
} 
to the extent that this is true, the erection of barriers to trade inhibits the transmission of ideas and prevents countries from attaining levels of wealth that might otherwise be possible. Coe, Helpman, and Hoffmaister (1995) show that R\&D spillovers from industrial countries to developing countries are substantial and that the extent of openness by LDC's to developed countries significantly impacts the extent of these spillovers which in turn positively affect growth in total factor productivity. Harberger (1984) also provides evidence that the existence of impediments to trade limits the growth of poor countries. Their removal, in the instances that this has occurred, has corresponded to heightened growth. This finding is corroborated and strengthened by empirical evidence presented in Sachs and Warner (1995) that compares growth rates of open and closed economies and finds that the former exhibit consistently higher growth. ${ }^{9}$

Nevertheless, as Lucas (1988) points out, the removal of trade barriers may be nothing more than a series of level effects disguised as growth effects. Indeed, level effects may be far from inconsequential and may even lead a country to leapfrog over initially wealthier countries. ${ }^{10}$ The theoretical framework developed here shows that movement towards free trade (or alternatively, movement towards protectionism) produces growth effects as well as level effects. So, while the model shows how unilateral or multilateral trade liberalization may lead to convergence by some - and divergence from others - all countries will be shown to experience long-term benefits in the form of faster steady-state growth as a result of trade reforms initiated by even one country.

\footnotetext{
${ }^{9}$ It also appears to be consistent with evidence in Balassa (1977), Michaely (1977), Ram (1990), Harrison (1991), Dollar (1992), Edwards (1992), Hansson and Henrekson (1992), Gould, Ruffin, and Woodbridge (1993), and Frankel and Romer (1995).

${ }^{10}$ See for example: Brezis, Krugman, and Tsiddon (1993), Goodfriend and McDermott (1994), and Motta, Thisse, and Cabrales (1995).
} 


\section{THE MODEL}

It is plausible to suppose that the foreign contribution to the local knowledge stock increases with the number of commercial transactions between domestic and foreign agents. That is, we may assume that international trade in tangible commodities facilitates the exchange of tangible ideas. ... It seems reasonable to assume therefore that the extent of the spillovers between any two countries increases with the volume of their international trade. (Grossman and Helpman, 1991a, 166-7)

Intuition of this kind, namely that international trade acts as a conduit as well as an impetus for the flow of knowledge across international borders, provides the underlying basis for the model to be developed here. Specifically, the goal of this section is to construct an open economy version of the neoclassical growth model which includes knowledge as a factor of production. When all countries are identical, with the exception of initial endowments, their behavior over time is similar to the predicted behavior of countries in the Solow-Cass-Koopmans model, namely convergence to identical long-run growth paths. The model developed in this paper departs from the usual neoclassical conclusions with regard to the impact of trade policy and the relative openness of countries. Here, the extent of openness not only affects output levels, but also has an impact on steady-state growth rates.

The model that we propose follows Romer (1990) by focusing on the importance of knowledge accumulation in the production of output. Physical capital is assumed here to be constant and is normalized to equal unity." Like Romer, we assume that growth in per capita output is due to the accumulation of knowledge. However, in contrast with his model, we make no distinction between firm specific knowledge and the aggregate stock of knowledge that an economy possesses.

Consider a world with $J$ countries, each of which produces a distinct good, with good $i$ being the output of country $i$. Let $n_{i}$ be the population growth rate in country $i$ and $c_{i j}(t)$ be the per capita quantity

\footnotetext{
"In a separate study (Ben-David and Loewy, 1997), we allow for the accumulation of both physical capital and knowledge. We find that the addition of the former leads to no substantive qualitative differences as far as steady-state outcomes are concerned. The inclusion of physical capital does, however, considerably constrain the examination of transitional dynamics. This in turn makes its inclusion less useful for the analysis conducted below.
} 
of good $j$ consumed in country $i$ at time $t$. Assuming that each agent in country $i$ is identical, the aggregate preferences of the agents in country $i$ are given by

$$
\int_{0}^{\infty} e^{-\left(\rho-n_{i}\right) t} L_{i}(0) \sum_{j=1}^{J} \alpha_{i j} \ln c_{i j}(t) d t
$$

where $\sum_{j=1}^{J} \alpha_{i j}=1$ and the discount rate, $\rho$, is common across all $J$ countries. In what follows, we normalize the initial population level in each country to one and, in order to avoid additional notation, assume that population size and labor force are equal. Note that the form of the utility function implies that country $i$ will trade with each of the remaining $J-1$ countries at every point in time. Since the same is true of all other countries, there will exist bilateral trade between every pair of countries.

Good $i$ is produced using labor and knowledge. Assuming that the production function is linear homogeneous in labor, this relationship may be written in per capita terms as

$$
y_{i}(t)=A H_{i}(t)^{\varepsilon_{i}}
$$

where $y_{i}(t)$ is per capita output, $H_{i}(t)$ is the aggregate stock of knowledge in country $i$ at time $t$, and $0<\varepsilon_{i}$. Note that as was the case with population growth rates, $n_{i}$, we permit the production parameter, $\varepsilon_{i}$, to differ across countries, although there is no requirement that this be the case. While the existence of such differences in $\varepsilon$ implies that countries' per capita incomes will grow at different rates in the steady state, as we show below, their steady-state rates of knowledge accumulation nevertheless will be the same.

Per capita income in country $i$ is the sum of per capita output plus per capita government tariff revenue. This income is then used to finance the consumption of both domestic and foreign goods. Let good 1 be the numeraire good, $p_{i}(t)$ be the time $t$ price of good $i$, and $\tau_{i j}$ be country $i$ 's tariff on imports from country $j$ ( $\tau_{i i}=0$ by definition). Tariffs are set exogenously and are assumed to be constant over time. Hence, country $i$ 's budget constraint is 


$$
\sum_{j=1}^{J} \frac{p_{j}(t) \cdot\left(1+\tau_{i j}\right)}{p_{i}(t)} c_{i j}(t)=A H_{i}(t)^{e_{i}}+g_{i}(t)
$$

where

$$
g_{i}(t)=\sum_{j \neq i} \frac{p_{j}(t) \tau_{i j} c_{i j}(t)}{p_{i}(t)}
$$

represents government revenues from the imposition of import tariffs which are transferred back to agents lump sum.

As in Lucas (1988), per capita growth in the steady state is obtained by positing that the technology of knowledge accumulation for country $i$ is constant returns to scale in the level of knowledge of country $i$. It is assumed further here that this technology is also constant returns to scale in the level of knowledge of all other countries. Moreover, the impact of country $j$ 's knowledge on country $i$ 's rate of knowledge accumulation depends upon (a) the degree of country $i$ 's access to country $j$ 's knowledge, and (b) country $i$ 's ability to absorb and utilize the accessible part of country $j$ 's knowledge.

As the quotation at the beginning of the section suggests, the share of country $j$ 's knowledge to which country $i$ has access (and therefore is the source of any potential knowledge spillovers), what we denote as $v_{i j}(t)$, is likely to be an increasing function of the volume of trade between the two countries. In line with what Grossman and Helpman (1991b) propose, $v_{i j}(t)$ is modeled as the ratio of country $i$ 's total trade with country $j$ divided by country $i$ 's aggregate output, or

$$
v_{i j}(t)=\frac{\frac{p_{j}(t)}{p_{i}(t)} c_{i j}(t)+\frac{L_{j}(t)}{L_{i}(t)} c_{j i}(t)}{y_{i}(t)}, \quad i \neq j
$$

where recall that $c_{i j}(t)$ represents country $i$ 's real per capita consumption of country $j$ 's good, $p_{i}(t)$ is the price of good $i$, and $L_{i}(t)$ is the size of the population in country $i$, each at time $t$.

Next, define $a_{i j}$ (where $0 \leq a_{i j} \leq 1$ ) as a constant representing the share of country $j$ 's accessible 
knowledge that can actually be utilized (or absorbed) by country $i$ as part of its own knowledge. ${ }^{12}$ One can view this variable as capturing Abramovitz's (1986) notion of "social capability" that determines the potential of a country to utilize existing technologies. Given these definitions, the accumulation of knowledge in country $i$ may be written as

$$
\dot{H}_{i}(t)=\phi\left[\sum_{j \neq i} a_{i j} \nu_{i j}(t) H_{j}(t)\right]+\left(\phi-\delta_{H}\right) H_{i}(t)
$$

where $\phi$ and $\delta_{H}$ represent the common productivity parameter and rate of depreciation of the knowledge stock (in terms of obsolescence or otherwise). ${ }^{13}$

Note that in the absence of trade (or with no capacity to absorb others' knowledge), domestic knowledge grows at the exogenous rate $\phi-\delta_{H}$. In such a case, the model reverts to a simple exogenous growth model which is essentially a modified version of the Solow model. Should it also be the case $\phi=\delta_{H}$, then there would be no per capita growth in autarky.

As far as the impact of tariffs on growth is concerned, recall (from Equation 5) that tariffs do not directly affect either the $v_{i j}$ 's or the rate of knowledge accumulation. However, as will be shown below, they do have a direct effect on consumption through their impact on market clearing prices. This in turn has an indirect effect on the $v_{i j}$ 's and therefore on $\dot{H}_{i} \cdot{ }^{14}$

\footnotetext{
${ }^{12}$ The assumption that $a_{i j}$ is a constant is made for simplification purposes only.

13 In contrast to our approach, Lucas (1993) assumes that the level of knowledge in other countries affects knowledge accumulation in country $i$ through the average level of knowledge worldwide. In his specification, complete openness is assumed.

${ }^{14}$ To the extent that a reduction in tariffs leads to an increase in growth rates, it follows that ad valorem subsidies funded by a lump-sum tax lead to even faster growth. However, if the lump-sum tax is replaced by the more common proportional income tax, then the growth outcome is less clear since the issue converts to an optimal income tax/trade subsidy problem that is beyond the scope of this paper.
} 


\section{SOLUTION}

Following Lucas (1988), suppose that the population in each country $j=1, \ldots, J$ is sufficiently large so that its private agents are atomistic. Hence, the first-order conditions for consumption and the budget constraint for country $i$ imply that

$$
c_{i i}=\alpha_{i i}\left(y_{i}+g_{i}\right)
$$

and

$$
c_{i j}=\alpha_{i j} \frac{p_{i}}{p_{j}\left(1+\tau_{i j}\right)}\left(y_{i}+g_{i}\right)
$$

Substituting Equations (8) into the expression for $g_{i}$, Equation (4), and then substituting the resulting expression into Equations (7) and (8) produces the closed form expressions

$$
c_{i i}=\alpha_{i i} Q_{i} y_{i}
$$

and

where

$$
c_{i j}=\alpha_{i j} \frac{p_{i}}{p_{j}\left(1+\tau_{i j}\right)} Q_{i} y_{i}
$$

$$
Q_{i}=\frac{\prod_{j \neq i}\left(1+\tau_{i j}\right)}{1+\sum_{j \neq i} \tau_{i j}\left(1-\alpha_{i j}\right)+\sum_{j \neq i, k} \sum_{k \neq i, j} \tau_{i j} \tau_{i k}\left(1-\alpha_{i j}-\alpha_{i k}\right)+\ldots+\left(1-\sum_{j \neq i} \alpha_{i j}\right) \prod_{j \neq i} \tau_{i j}}
$$

Recalling that good 1 is the numeraire, the prices of goods $2, \ldots, J$ are found by substituting Equations (9) and (10) for each $(i, j)$ into $J-1$ of the following market clearing conditions

$$
c_{i i}(t)+\sum_{j \neq i} \frac{L_{j}(t)}{L_{i}(t)} c_{j i}(t)=A H_{i}(t)^{\varepsilon_{i}}
$$

Solving this system implies that

$$
p_{i}=\pi_{i} \frac{L_{1} y_{1}}{L_{i} y_{i}} \quad i=2, \ldots, J
$$

where $\pi_{i}$ is a function of $\hat{\alpha}_{i j}=\frac{\alpha_{i j} Q_{i}}{1+\tau_{i j}}$ for all $i$ and $j(i \neq j)$. For example, if $J=2$, then $\pi_{1}=1$ 
(trivially) and $\pi_{2}=\hat{\alpha}_{12} / \hat{\alpha}_{21}$. More interestingly, if $J=3$, then again $\pi_{1}=1$, while

$$
\pi_{2}=\frac{\hat{\alpha}_{12}\left(\hat{\alpha}_{31}+\hat{\alpha}_{32}\right)+\hat{\alpha}_{13} \hat{\alpha}_{32}}{\hat{\alpha}_{21}\left(\hat{\alpha}_{31}+\hat{\alpha}_{32}\right)+\hat{\alpha}_{23} \hat{\alpha}_{31}}
$$

and

$$
\pi_{3}=\frac{\hat{\alpha}_{13}\left(\hat{\alpha}_{21}+\hat{\alpha}_{23}\right)+\hat{\alpha}_{12} \hat{\alpha}_{23}}{\hat{\alpha}_{21}\left(\hat{\alpha}_{31}+\hat{\alpha}_{32}\right)+\hat{\alpha}_{23} \hat{\alpha}_{31}}
$$

Unilateral and/or multilateral trade liberalization influences prices through the affected $\hat{\alpha}$ 's, and the resultant price dynamics lead to subsequent changes in trade behavior which in turn lead to corresponding increases and decreases, as the case may be, in the extent of trade of the individual countries. Hence, the eventual impact on steady-state growth is not readily apparent - although, as will be shown below, it is positive. (Section 5 below provides some examples of these dynamics during the transitional period as well as on the eventual steady state.)

Country $i$ 's measure of openness towards country $j, v_{i j}$, is found by substituting into Equation (5) the expressions for $c_{i j}$ and $c_{j i}$ from Equation (10) and $p_{i}$ and $p_{j}$ from Equation (12). Doing so yields

$$
v_{i j}=\hat{\alpha}_{i j}+\hat{\alpha}_{j i} \frac{\pi_{j}}{\pi_{i}}
$$

for all $i \neq j$. Given its significance in what follows, note that each $v_{i j}$ equals a constant which is a function of, among other things, the entire set of tariff rates, $\left\{\tau_{i j}\right\}_{i \neq j}$.

Finally, although there is no requirement that bilateral trade be balanced between any two countries $i$ and $j$, the market clearing conditions (11), national budget constraint (3), and the government budget constraint (4) jointly imply (in the absence of international capital flows) that each country maintains multilateral trade balance at every point in time. In other words

$$
L_{i}(t) \sum_{j \neq i} p_{j}(t) c_{i j}(t)=\sum_{j \neq i} p_{i}(t) L_{j}(t) c_{j i}(t) \quad \forall i
$$

Turning to the dynamic behavior of country $i$, the specification of Equation (6) implies that this 
is governed by the system of all $J$ versions of Equation (6). Writing this system in vector notation, it follows that

$$
\dot{\mathbf{H}}(t)=\boldsymbol{\Phi} \cdot \mathbf{H}(t)
$$

where $\mathbf{H}(t)=\left(H_{1}(t), \ldots, H_{J}(t)\right)^{\prime}$ and

$$
\Phi=\left[\begin{array}{cccc}
\phi-\delta_{H} & \phi a_{12} v_{12} & \ldots & \phi a_{1 J} v_{1 J} \\
\phi a_{21} v_{21} & \phi-\delta_{H} & \ldots & \phi a_{2 J} v_{2 J} \\
\cdot & \cdot & & \cdot \\
\cdot & \cdot & \ddots & \cdot \\
\cdot & \cdot & & \cdot \\
\phi a_{J 1} v_{J 1} & \phi a_{J 2} v_{J 2} & \ldots & \phi-\delta_{H}
\end{array}\right]
$$

Since $\Phi$ is a matrix of constants (recall Equation [15]), the solution to Equation (16) may be written as

$$
\mathbf{H}(t)=\sum_{j=1}^{J} \xi_{j} e^{\mu_{j} t} \mathbf{x}_{j}
$$

where $\mu_{1}, \ldots, \mu_{J}$ are the eigenvalues of $\Phi, \mathbf{x}_{1}, \ldots, \mathbf{x}_{J}$ are the associated eigenvectors with $\mathbf{x}_{i}=\left(x_{1 i}, \ldots, x_{J i}\right)^{\prime}$, and $\xi_{1}, \ldots, \xi_{J}$ are constants determined by the initial conditions, $H_{1}(0), \ldots, H_{J^{\prime}}(0)$, and the eigenvectors.

Let $\mu_{1}$ be the largest eigenvalue of $\Phi$. As long as at least one $a_{i j}>0$ for each $i$ and because all goods are traded (i.e., $v_{i j}>0$ ), it follows that $\mu_{1}>\phi-\delta_{H}$. Since the steady state is, by definition, an equilibrium in which endogenous variables (here in per capita terms) grow at constant rates, Equation (17) implies that in each country $i$ the steady-state level of knowledge, $H_{i}$, must grow at the common rate $\gamma_{H}^{*}=\mu_{1}$ (where the asterisk denotes steady-state values). Furthermore, by the definition of $\mathbf{x}_{1}$, it follows that in the steady state the relative levels of knowledge, $H_{j}^{*} / H_{i}^{*}$, are given by $x_{j 1} / x_{i 1}$ which are also constant. Note that $\mu_{1}$ is increasing in every $v_{i j}$ since the more open is country $i$ towards country $j$, the faster it, and hence, every other country that trades with country $i$ grows. Since the utility function guarantees that all countries trade with each other, then even if country $i$ becomes more open only 
towards country $j$, all countries grow faster in the steady state. Of course, in such a case, country $i$ also experiences positive level effects relative to its trade partners.

These results, together with those from above, imply that the steady-state behavior of each country may be characterized by the following relationships:

$$
\gamma_{c_{H}}^{*}=\gamma_{y_{i}}^{*}=\varepsilon_{i} \gamma_{H}^{*} \quad ; \quad \gamma_{c_{y}}^{*}=n_{j}-n_{i}+\varepsilon_{j} \gamma_{H}^{*}
$$

where $\gamma_{x}^{*}$ denotes the steady-state rate of growth of any variable $x$. Therefore, the rate of knowledge accumulation is identical for each country, while the growth rate of per capita output and consumption may vary if the production parameters $\left(\varepsilon_{i}\right.$ 's) and/or the population growth rates $\left(n_{i}\right.$ 's) differ. To the extent that these parameters are the same, so too will be the steady-state growth rates of per capita output and consumption in each country.

To better highlight the short and long-run effects that changes in tariff policy may have on the initiating country, as well as on its trade partners, the focus now shifts to a number of simulations of the model. These facilitate a clearer understanding of the impact of the liberalization process on output levels and growth rates by detailing the changes that take place during the transition from one steady state to the next.

\section{Simulations}

The focus in this section will be on a three-country world since this permits an analysis of (among other things) the effects of unilateral trade liberalization on the part of the country with the middle level of income on both its wealthier and poorer trade partner. Within such a scenario, can the liberalizing country catch-up or even surpass the per capita income level of the wealthier country? Would the longrun growth effects of such a policy be different if it were instituted instead (or as well) by the wealthy country or the poor country? The following simulations show that a variety of conclusions are possible. 


\section{Simulation 1: Different Initial $\boldsymbol{H}$ (Baseline Case)}

The first simulation, which also serves as our baseline case, assumes that all three countries are identical save for their initial levels of knowledge. For simplicity, $A, L_{i}(0), i=1,2,3$, and $a_{i j}, i, j=$ $1,2,3, i \neq j$, are set at unity while $\mathbf{H}(0)=(1,2,3)^{\prime}, \phi=0.1, \delta_{H}=0.05, \rho=0.04, n_{i}=0.02, \varepsilon_{i}$ $=0.3, \alpha_{i i}=0.6$, and $\alpha_{i j}=0.2$ where $i, j=1,2,3$ and $i \neq j$. Hence, country 1 is initially the poorest country and country 3 is initially the wealthiest country. Also, consumers in each country give most weight to the utility derived from consuming their own good while giving less, but equal, weight to the utility derived from consuming the two imported goods. Tariffs are set at the rate of $75 \%$ by each country $i$ on both partner's imported goods. This relatively high rate is not mandatory and is primarily used for illustrative purposes in order to yield clearer distinctions in the graphs which follow. The qualitative behavior described below works for lower tariffs as well.

Given these baseline parameters, these three countries converge to identical per capita output levels and growth rates (of $3.04 \%$ annually) in the steady state. The outcome of this simulation, with respect to levels and growth rates, is similar to that of the standard neoclassical model when countries differ only by their initial endowments. In that model, as is the case here, if countries begin from different starting points, or alternatively, if a country experiences a shock to its inputs, countries eventually return to their original steady-state path. ${ }^{15}$

\section{Simulation 2: Different Initial $\boldsymbol{H}$ and a Reduction in a Single Tariff, $\tau_{23}$}

Consider once again the baseline economies of Simulation 1. Suppose that starting in period 15 , country 2 (the initially middle-income country) unilaterally begins to reduce its tariffs on imports from country 3 (the initially wealthy country) at the rate of 15 percentage points per period. Hence, this tariff is completely eliminated by period 20 . Suppose that no other tariff reductions occur.

\footnotetext{
${ }^{15}$ To the extent that the $a_{i j}$ 's differ from country to country - for example, if the ability of each country to absorb knowledge spillovers is not the same - then the countries will converge to different, but parallel, growth paths.
} 
Panels A-E of Figure 1 include the 14 periods prior to the tariff reduction, the 5 periods of tariff reduction, and 31 post-liberalization periods. The unilateral tariff reduction sets in motion a series of relative price changes and subsequent movements in the bilateral shares of output being traded by the three countries. These combined changes affect the growth paths of the individual countries, both in terms of their relative income levels as well as in their steady-state growth rates.

The decrease in $\tau_{23}$ implies that there is a reduction in the gross of tax price of good 3 in country $2, p_{3}\left(1+\tau_{23}\right) / p_{2}$, which in turn increases $c_{23}$, the imports by 2 from 3 . Import substitution in country 2 then leads to a reduction in $c_{21}$. The increase in demand for good 3 increases its price, $p_{3}$ (see Panel A), and therefore improves country 3's terms of trade. This in turn increases $c_{31}$ and $c_{32}$. The increase in $p_{3}$ also affects country 1 's imports from country 3 , leading to a decrease in $c_{13}$. To determine the effect on $c_{12}$, note first that the increased exports from 2 to 3 and the increased imports by 2 from 3 coupled with the increase in the relative price of the imports unambiguously increases $v_{23}$. Next, note that by Equation (6) this increase causes an increase in the knowledge stock of country 2. Equation (2) then implies that the supply of good 2 rises which in turn, decreases its price (see Panel A). The resultant decline in $p_{2}$ increases $c_{12} \cdot{ }^{16}$ As Panel $\mathrm{B}$ indicates, four of the six $v_{i j}$ 's rise while two others fall. However, as the discussion of long-run results below shows, the decreases are more than offset by increases in the remaining $v_{i j}$ 's and a reduction in $\tau_{23}$ leads to an increase in the steady-state growth rate that is common to all three countries.

Panel $\mathrm{C}$ shows that the main beneficiary in the short run is country 2 , the liberalizing country, whose income overtakes that of country 3 to become the wealthiest country. This result is seen more clearly in Panel D, which shows the income gap between country 3 and the other countries, and in Panel E, which displays each country's growth rate. The initial income gap between countries 3 and 2 is eventually eliminated and then is reversed as country 2 surpasses country 3 . While there is eventual

\footnotetext{
${ }^{16}$ This pattern of results is by no means unique to this example. Similar results obtain whenever there is a unilateral decrease in a single tariff.
} 
income convergence between countries 1 and 3, the gap between them and country 2 continues to exist in the steady state since all countries grow at the same rate in the long run.

As a result of the unilateral liberalization by country 2 on imports from country 3 , the steady-state growth rate for each country rises from $3.04 \%$ found in Simulation 1 to $3.17 \%$. Because of the similarity in preferences, it turns out not to matter which country embarks on trade reform. Growth rates rise to $3.17 \%$ independently of country choice. Naturally, the level effects would differ.

If one country decides to eliminate tariffs on both of its imports, then long-run growth rates rise to $3.26 \%$. Note that while the choice of liberalizing country is immaterial as far as growth is concerned, this is not the case when the issue is output levels. If any pair of countries moves to completely free trade, then the income levels of the two will converge - with an income gap persisting between the two countries that fully eliminate tariffs and the one that does not - and steady-state growth rates will rise to $3.49 \%$. If all three countries remove all tariffs, then the steady-state growth rate increases to $3.73 \%$ and all three income levels converge along the new, steeper, growth path (see Panel F).

\section{Simulation 3: Liberalization Among Developed Countries}

Suppose that new "worldwide" trade agreements mandate that all tariffs must be reduced by a third. At the same time, suppose further that the two wealthier countries sign a free trade agreement stipulating that they must remove all barriers to trade with one another within 5 years. In other words, while countries 2 and 3 completely eliminate their tariffs on trade with each other, they partially reduce their tariffs on trade with country 1 , as does 1 on trade with 2 and 3 . This example is not particularly different from the agreement that led the European Economic Community to initiate a formal timetable for the complete removal of all remaining tariffs between 1959 and 1968, and the subsequent Kennedy Round Agreements within the GATT framework that led to across-the-board partial tariff reductions beginning in 1968. Finally, suppose that in each country greater weight is given to the utility of consumption of the import of the wealthier trade partner, letting the $\alpha_{i i}$ 's equal 0.6 as before and the $\alpha_{i j}$ 's 
equal 0.267 and 0.133 for the more developed and the less developed partners, respectively.

The effects of these policies are depicted in Figure 2 which shows that the top two countries converge to similar paths while maintaining a gap with the poorer country. Thus, while tariff reductions boost trade (Panel A) and all countries move to faster steady-state growth of $3.51 \%$ (as indicated in Panel B), an income gap with the less developed country continues to exist (Panels C and D).

The presence of both income convergence and faster growth appear to describe the major postwar liberalization experiences fairly well. Continuing with the example of the original EEC countries, a trade barrier index that is a composite measure of tariffs and quotas for the EEC between 1950 and 1968 is constructed in Ben-David (1994) and plotted at the bottom of Figure 3, Panel A. ${ }^{17}$ Although the Community was officially created in the late fifties, member countries began to liberalize trade in varying degrees beginning in the late forties. The removal of trade barriers manifested itself in an increasing ratio of total intra-EEC trade to total EEC output, depicted as $v_{E E C}$ in Panel A. As is evident in Panel B, in the years between 1870 and World War II, the standard deviations of the EEC countries' log real per capita incomes had been relatively constant. However, with the elimination of trade impediments following the war, this measure of income disparity among the countries (labeled $\sigma_{E E C}$ in Panel A) began to fall. ${ }^{18}$

As the liberalization process tapered off in the late 1960 s, so too did the fall in $\sigma_{E E C}$ and the rise in $v_{E E C}$ (Ben-David, 1993, 1994). Note that the convergence process does not end immediately with the formal end of the EEC's liberalization period. This is consistent with the simulated convergence process (in Panels C and D of Figure 2) which does not immediately end following the complete elimination of tariffs.

\footnotetext{
${ }^{17}$ Although 1968 marked the end of the formal period of trade liberalization among the six founding members of the Community, some additional trade impediments, both informal and formal (most notably regarding trade in agricultural goods), continued to exist.

${ }^{18}$ Data Sources: Data for standard deviations in Panel A comes from Summers and Heston (1995), while the data for construction of the $v$ 's comes from the International Monetary Fund International Financial Statistics and Direction of Trade data. Data used in Panel B comes from Maddison (1991).
} 
Figure 4 provides some visual evidence that this convergence did not come at the expense of slower growth by the initially wealthy countries of the Community. ${ }^{19}$ As predicted by the model (and represented by countries 2 and 3 in Figure 2, Panel C), following World War II each one of the EEC countries moved to a new and steeper growth path that exceeded its former path (which is extrapolated into the postwar period to facilitate comparisons) ${ }^{20}$ Also included in Figure 4 are long-run plots of each country's total export to GDP ratios which indicate a clear difference in the extent of postwar trade compared to prewar trade - and a similarity to the behavior of $v_{23}$ and $v_{32}$ in Panel A of Figure 2 .

Ben-David $(1993,1994)$ shows how this type of trade liberalization scenario was repeated between the U.S. and Canada as well as between the EEC and EFTA (European Free Trade Association). In each case, these episodes culminated in increased trade and significant income convergence by the liberalizing countries. Finally, the lack of convergence, or catch-up, by the poorer countries (also evident in Figure 2, Panels C and D) has been cited by many authors. Examples include Baumol (1986), Romer (1986), Lucas (1988), and Ben-David (1995).

\section{CONCLUSION}

This paper focuses on the impact of international trade on income convergence and economic growth. While the traditional trade literature addresses the impact of trade on the equalization of factor prices, it does not necessarily imply that incomes should converge as well. On the other hand, the Solow-Cass-Koopmans growth model predicts income convergence, but this occurs within autarky. In addition, both frameworks are silent on the possible steady state impact of trade liberalization. The theoretical framework developed here provides a simple model that bridges these gaps while illustrating

\footnotetext{
${ }^{19}$ Data source: Maddison (1991)

${ }^{20}$ The extrapolations in these figures were done using standard augmented-Dickey-Fuller tests. Since the sole purpose of these extrapolations is to facilitate clearer visual inspections of the postwar and prewar differences, the regression results are not reported here so as not to diffuse the main focus of this paper. However, these results are available from the authors upon request. For a more comprehensive analysis of long-run growth rates, see Ben-David and Papell (1995b).
} 
the impact of tariff reductions not only the steady state outcomes, but on transitional behavior as well and not only the growth effects, but the changes in the individual output levels of countries. While the model is purposefully simple, so as to enable such an analysis, it goes beyond the common two-country models to permit examinations of unilateral and multilateral policy changes on the countries enacting the changes, as well as on the remaining countries.

The more open an economy, the greater the competitive pressures upon it and the greater the need for it to incorporate foreign knowledge into its production processes in order to be able to compete with foreign firms. This provides the basis for our assumption that trade flows between countries facilitate the diffusion of knowledge and spur the growth process. Like the Solow-Cass-Koopmans model, the theoretical framework presented here predicts that countries with similar technological parameters exhibit similar per capita growth in the long run. In this model however, steady-state growth rates depend upon the rate of knowledge accumulation which in turn is a function of the stocks of knowledge worldwide. Each country accesses foreign knowledge by conducting trade with other countries. The extent of this trade dictates the extent of the knowledge spillovers that will ensue, and hence, the rate of output growth. Countries with identical tariff structures converge to the same steady-state growth path and to similar per capita outputs in the long run.

Unilateral trade liberalization (in the form of tariff reductions) leads to terms of trade dynamics that result in changes in the extent of trade between countries - with some bilateral trade rising and other bilateral trade falling. The output of countries is affect in two ways. First, there is a level effect captured by the liberalizing country which may enable it to catch up with, and possibly leapfrog over initially wealthier countries. Second, and most important, there is a positive growth effect which affects all countries in the long run. If wealthy countries (in per capita terms) are also the countries with the greatest stocks of knowledge, then the elimination of tariffs on these countries' trade will have the greatest growth effects.

Empirical evidence appears to corroborate the model's predictions. Specifically, the increasing 
tendency towards trade liberalization during the postwar period has led to a significant convergence in income levels within the EEC, between the U.S. and Canada, and between the EEC and EFTA. The faster growth (by the poorer countries in each group) that caused the convergence in levels did not come about at the expense of their wealthier trade partners. In fact, each of these liberalizing countries moved to growth paths that were higher during the postwar period than during the period between 1870 and the start of World War II.

Finally, while trade liberalization and income convergence characterize many of the world's wealthier countries, this is not an apt characterization of what has occurred with the poorer countries. These countries tend to surround themselves with greater walls of protection which also, in the context of the model presented here, act as a buffer that limits knowledge spillovers to them. Hence, the income gap between these countries and the developed world continues to exist, and to the extent that this model is correct, will continue to exist until the barriers start to come down. 


\section{REFERENCES}

Abramovitz, Moses (1986), "Catching Up, Forging Ahead, and Falling Behind," Journal of Economic History, 46, 385-406.

Backus, David K., Patrick J. Kehoe and Timothy J. Kehoe (1992), "In Search of Scale Effects in Trade and Growth," Journal of Economic Theory, 58, 377-409.

Balassa, Bela (1977), "Exports and Economic Growth: Further Evidence," Journal of Development Economics, 5, 181-189.

Baldwin, Richard E. (1992), "On the Growth Effects of Import Competition," NBER Working Paper No. 4045 .

Baumol, William J. (1986), "Productivity Growth, Convergence, and Welfare: What the Long-Run Data Show," American Economic Review, 76, 1072-1085.

Baumol, William J., Sue Ann B. Blackman and Edward N. Wolff (1989), Productivity and American Leadership: The Long View, Cambridge, MA: MIT Press.

Ben-David, Dan (1993), "Equalizing Exchange: Trade Liberalization and Income Convergence," Quarterly Journal of Economics, 108, 653-79.

Ben-David, Dan (1994), "Income Disparity Among Countries and the Effects of Freer Trade," Economic Growth and the Structure of Long Run Development, in Luigi L. Pasinetti and Robert M. Solow (eds.), London: Macmillan, 45-64.

Ben-David, Dan (1995), "Convergence Clubs and Diverging Economies," Foerder Institute Working Paper No. 40-95.

Ben-David, Dan (1996), "Trade and Convergence Among Countries," Journal of International Economics, 40, 279-298.

Ben-David, Dan and Michael B. Loewy (1997), "Knowledge Dissemination, Capital Accumulation, Trade and Endogenous Growth," Sackler Institute working paper no. 3-97.

Ben-David, Dan and David H. Papell (1995a), "Slowdowns and Meltdowns: Postwar Growth Evidence from 74 Countries," CEPR Discussion Paper No. 1111.

Ben-David, Dan and David H. Papell (1995b), "The Great Wars, the Great Crash, and Steady State Growth: Some New Evidence About an Old Stylized Fact, " Journal of Monetary Economics, 36, 453-475.

Ben-David, Dan and David H. Papell (1996), "International Trade and Structural Change," CEPR Discussion Paper No. 1568, forthcoming: Journal of International Economics.

Brezis, Elise S., Paul R. Krugman, and Daniel Tsiddon (1993), "Leapfrogging in International Competition: A Theory of Cycles in National Technological Leadership," American Economic Review, 83, 1211-1219. 
Bruno, Michael (1984), "Raw Materials, Profits, and the Productivity Slowdown," Quarterly Journal of Economics, 99, 1-12.

Cass, David (1965), "Optimum Growth in an Aggregative Model of Capital Accumulation," Review of Economic Studies, 32, 233-40.

Caves, Richard E. (1965), "Vent for Surplus Models of Trade and Growth," in R. E. Baldwin et al., Trade Growth and the Balance of Payments, Chicago: Rand McNally.

Coe, David T., Elhanan Helpman, and Alexander W. Hoffmaister (1995), "North-South R\&D Spillovers," NBER working paper No. 5048.

Corden, W. M. (1971), "The Effects of Trade on the Rate of Growth," in Trade, Balance of Payments and Growth: Papers in International Economics in Honer of Charles P. Kindleberger, J. N. Bhagwati, R. W. Jones, R. A. Mundell, and J. Vanek (eds.), Amsterdam: North Holland, chap. 6.

De Long, J. Bradford and Lawrence H. Summers (1992), "Macroeconomic Policy and Long-Run Growth," Policies for Long-Run Economic Growth, Federal Reserve Bank of Kansas City, 93128.

Dollar, David (1992), "Outward-oriented Developing Economies Really Do Grow More Rapidly: Evidence from 95 LDCs, 1976-1985," Economic Development and Cultural Change, 40, 523544.

Dollar, David, Edward N. Wolff, and William J. Baumol (1988), "The Factor-Price Equalization Model and Industry Labor Productivity: An Empirical Test across Countries," in Robert C. (ed.), Empirical Methods for International Trade, Cambridge: MIT Press, 23-47.

Easterly, William, Robert King, Ross Levine, and Sergio Rebelo (1994), Economic Growth and the Structure of Long Run Development, in Luigi L. Pasinetti and Robert M. Solow (eds.), London: Macmillan, 75-89.

Eaton, Jonathan and Samuel Kortum (1994), "International Patenting and Technology Diffusion," NBER Working Paper No. 4931.

Edwards, Sebastian (1992), "Trade Orientation, Distortions and Growth in Developing Countries," Journal of Development Economics, 99, 31-57.

Edwards, Sebastian (1993), "Openness, Trade Liberalization, and Growth in Developing Countries," Journal of Economic Literature, 31, 1358-1393.

Feenstra, Robert (1996), "Trade and Uneven Growth," Journal of Development Economics, 49, 229-256.

Fieleke, Norman S. (1994), "Is Global Competition Making the Poor Even Poorer?," New England Economic Review, November-December, 3-16.

Frankel, Jeffrey A. and David Romer (1995), "Trade and Growth," Unpublished Working Paper. 
Goodfriend, Marvin and John McDermott (1994), "A Theory of Convergence, Divergence, and Overtaking," unpublished working paper.

Gould, David M., Roy J. Ruffin and Graeme L. Woodbridge (1993), "The Theory and Practice of Free Trade," Federal Reserve Bank of Dallas Economic Review, Fourth Quarter, 1-16.

Griliches, Zvi (1980), "R \& D and the Productivity Slowdown," American Economic Review Paper and Proceedings, 70, 343-8.

Grossman, Gene and Elhanan Helpman (1991a), Innovation and Growth in the Global Economy, Cambridge: MIT Press.

Grossman, Gene M. and Elhanan Helpman (1991b), "Trade, Knowledge Spillovers, and Growth," European Economic Review, 35, 517-526.

Grossman, Gene M. and Elhanan Helpman (1995), "Technology and Trade," in Handbook of International Economics, vol. III, in G. Grossman and K. Rogoff (eds.), Amsterdam: Elsevier Science Publishers, 1279-1337.

Hansson, Pär and Magnus Henrekson (Nov 1992), "What Makes a Country Socially Capable of Catching Up?," Weltwirtschaftliches Archiv, 130, 152-174.

Harberger, Arnold C. (1984), World Economic Growth, San Francisco: ICS Press.

Harrison, Anne (1991), "Openness and Growth: A Time-Series Cross Country Analysis for Developing Countries," World Bank Working Paper No. 809.

Helpman, Elhanan and Paul R. Krugman (1985), Market Structure and Foreign Trade, Cambridge: MIT Press.

International Monetary Fund, Direction of Trade Statistics Yearbook, Washington, D.C., various editions.

International Monetary Fund, International Financial Statistics Yearbook, Washington, D.C., various editions.

Johnson, Harry G. (1971), "The Theory of Trade and Growth: A Diagrammatic Analysis," in Trade, Balance of Payments and Growth: Papers in International Economics in Honor of Charles P. Kindleberger, J. N. Bhagwati, R. W. Jones, R. A. Mundell, and J. Vanek (eds.), Amsterdam: North Holland, chap. 7.

Jones, Larry E. and Rodolfo Manuelli (1990), "A Convex Model of Equilibrium Growth: Theory and Policy Implications," Journal of Political Economy, 96, 1108-1038.

Kindleberger, Charles P. (1962), Foreign Trade and the National Economy, New Haven: Yale University Press.

Koopmans, Tjalling C. (1965), "On the Concept of Optimal Economic Growth," The Econometric Approach to Development Planning, Pontificia Academia Scientiarum, Amsterdam: North-Holland Publishing Co. 
Lucas, Robert E. Jr. (1988), "On the Mechanics of Economic Development," Journal of Monetary Economics, 22, 3-42.

Lucas, Robert E. Jr. (1993), "Making a Miracle," Econometrica, 61, 251-272.

Maddison, Angus (1991), Dynamic Forces in Capitalist Development: A Long-Run Comparative View, Oxford: Oxford University Press.

Marin, Dalia (1995), "Learning and Dynamic Comparative Advantage: Lessons from Austria's Post-war Pattern of Growth For Eastern Europe," CEPR Discussion Paper No. 1116.

Michaely, Michael (1977), "Exports and Growth: An Empirical Investigation," Journal of Development Economics, 4, 49-53.

Motta, Massimo, Jacques-François Thisse and Antonio Cabrales (1995), "On the Persistence of Leadership or Leapfrogging in International Trade," CEPR Discussion Paper No. 1106.

Myrdal, Gunnar (1957), Economic Theory and Under-Developed Regions, London: Duckworth \& Co.

Myrdal, Gunnar (1959), Development and Under-Development, Cairo: National Bank of Egypt.

Olson, Mancur (1982), The Rise and Decline of Nations: Economic Growth, Stagflation and Social Rigidities, New Haven: Yale University Press.

Parente, Stephen L. and Edward C. Prescott (1994), "Barriers to Technology Adoption and Development," Journal of Political Economy, 102, 298-321.

Prebisch, Raul (1950), The Economic Development of Latin America and Its Principal Problems, New York: United Nations.

Ram, Rati (1990), "Imports and Economic Growth: A Cross-Country Study," Economia Internazionale, $43,45-66$.

Rassekh, Farhad and Henry Thompson (1996), "Micro Convergence and Macro Convergence: Factor Price Equalization and Per Capita Income," unpublished working paper, University of Hartford.

Rivera-Batiz, Luis A. and Paul M. Romer (1991a), "International Trade with Endogenous Technological Change," European Economic Review, 35, 971-1004.

Rivera-Batiz, Luis A. and Paul M. Romer (1991b), "Economic Integration and Endogenous Growth," Quarterly Journal of Economics, 106, 531-555.

Rodrik, Dani (1992), "The Rush to Free Trade in the Developing World: Why so Late? Why Now? Will it Last?," NBER Working Paper No. 3947.

Romer, Paul (1986), "Increasing Returns and Long-Run Growth," Journal of Political Economy, 94, 1002-1038. 
Romer, Paul M. (1987), "Crazy Explanations for the Productivity Slowdown," NBER Macroeconomics Annual, 163-202.

Romer, Paul M. (1990), "Endogenous Technological Change," Journal of Political Economy, 98, S71-S102.

Romer, Paul M. (1994), "New Goods, Old Theory, and the Welfare Costs of Trade Restrictions," Journal of Development Economics, 43, 5-38.

Rosenberg, Nathan (1980), Inside the Black Box, Cambridge, England: Cambridge University Press.

Ruffin, Roy J. (1993), "Endogenous Growth and International Trade," Review of International Economics, 2, 27-39.

Sachs, Jeffrey D. and Andrew Warner (1995), "Economic Reform and the Process of Global Integration," Brookings Papers on Economic Activity, no. 1, 1-95.

Samuelson, Paul A. (1948), "International Trade and the Equalisation of Factor Prices," Economic Journal, 58, 163-84.

Slaughter, Mathew J. (1997), "Per Capita Income Convergence and the Role of International Trade," NBER Working Paper No. 5897.

Solow, Robert M. (1956), "A Contribution to the Theory of Economic Growth," Quarterly Journal of Economics, 70, Reprinted in Joseph E. Stiglitz and Hirofumi Uzawa (eds.), Readings in the Modern Theory of Economic Growth, Cambridge: MIT Press, 58-87.

Singer, H. (1950), "The Distribution of Gains between Investing and Borrowing Countries," American Economic Review, 40, 473-85.

Stokey, Nancy L. (1991), "The Volume and Composition of Trade Between Rich and Poor Countries," Review of Economic Studies, 58, 63-80.

Summers, Robert and Alan Heston (1995), "The Penn World Table (Mark 5.6)"

Young, Alwyn (1991), "Learning By Doing and the Dynamic Effects of International Trade," Quarterly Journal of Economics, 106, 369-405. 
Figure 1: Unilateral Tariff Reductions by Country 2 on Imports from Country 3 $1=$ Poor Country $\quad 2=$ Middle Income Country $\quad 3=$ Rich Country

Panel A:

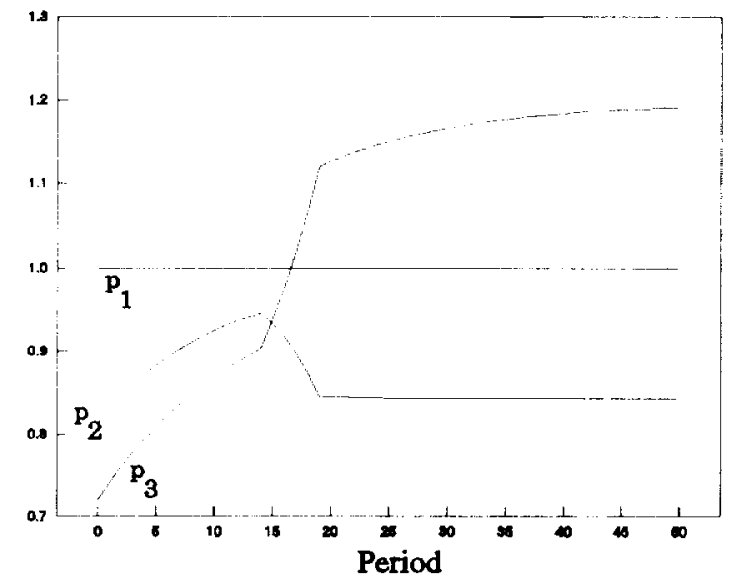

Panel C:

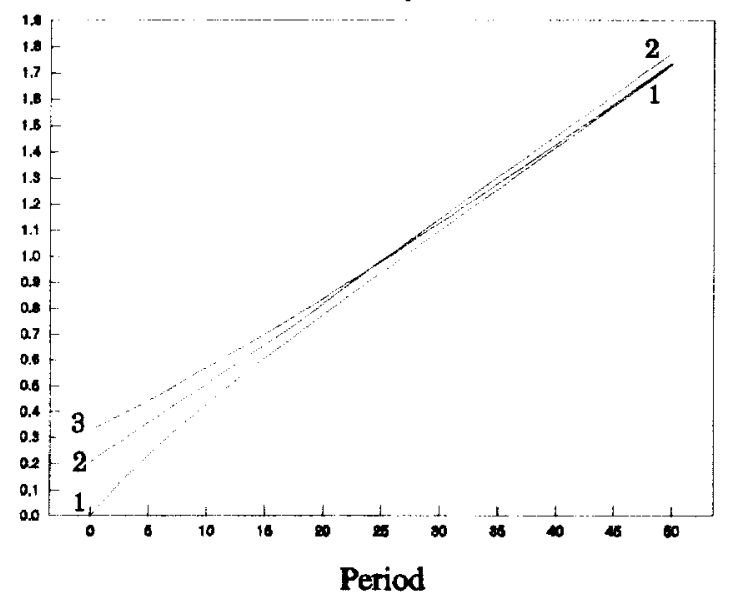

Panel E: Growth Rates of Per Capita Output

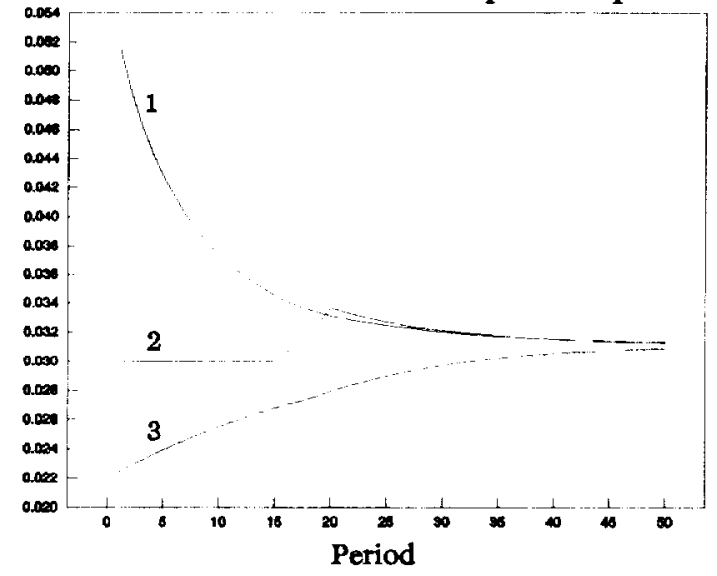

Panel B: $\quad$ Trade - Output Ratios $\left(v_{i j}\right)$

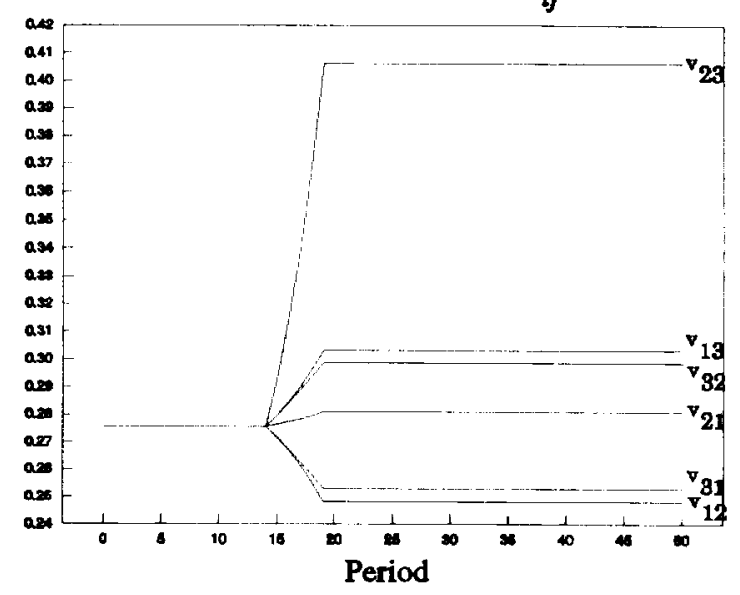

Panel D: $\quad \operatorname{Ln} y_{3}$ minus $\quad \operatorname{Ln} y_{i} \quad(i=1,2)$

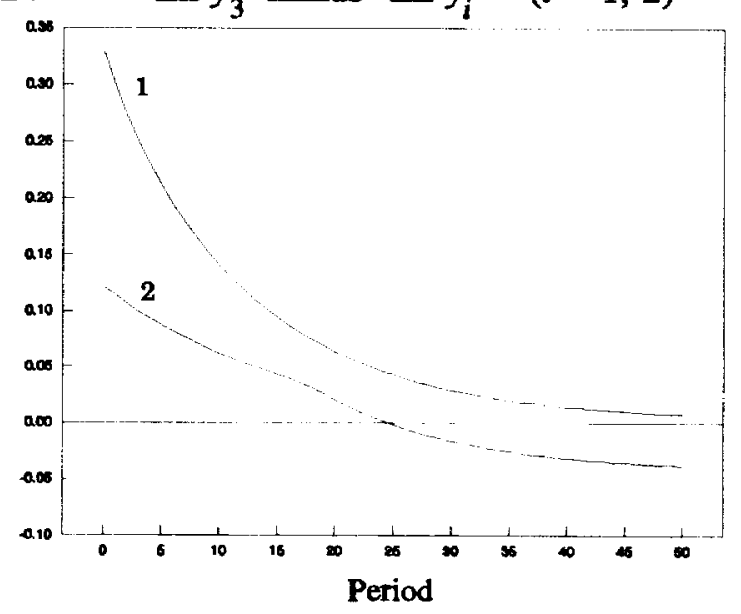

Movement to Free Trade by All Countries Panel F: $\quad$ Ln y

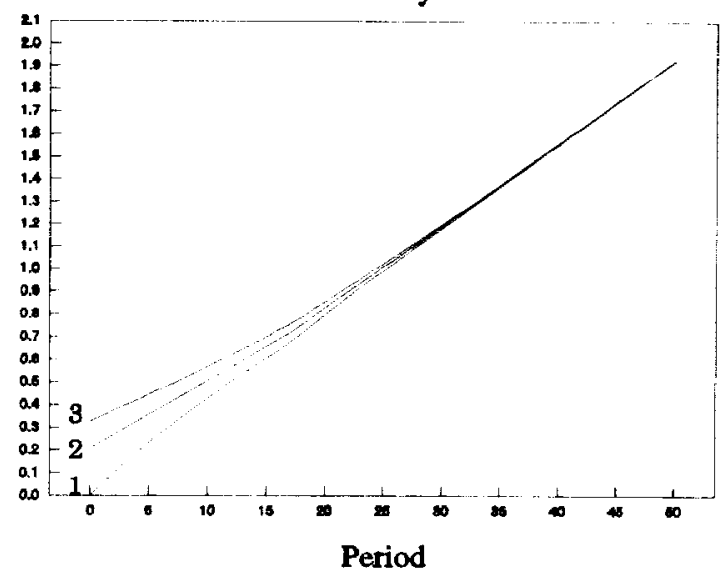


Figure 2: Free Trade Only Among the Developed Countries

$$
1=\text { Poor Country } \quad 2=\text { Middle Income Country } \quad 3=\text { Rich Country }
$$

Panel A

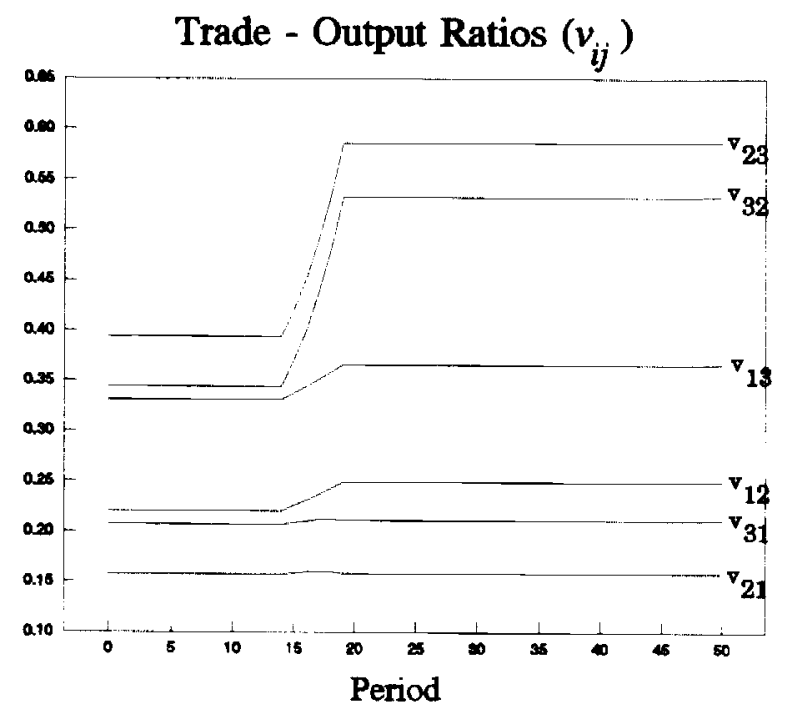

\section{Panel C}

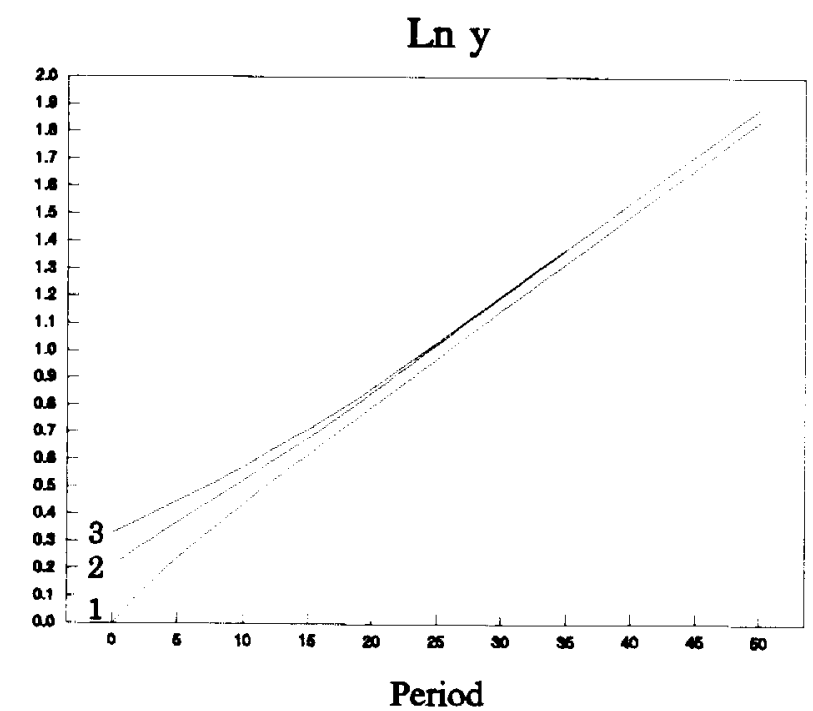

Panel B

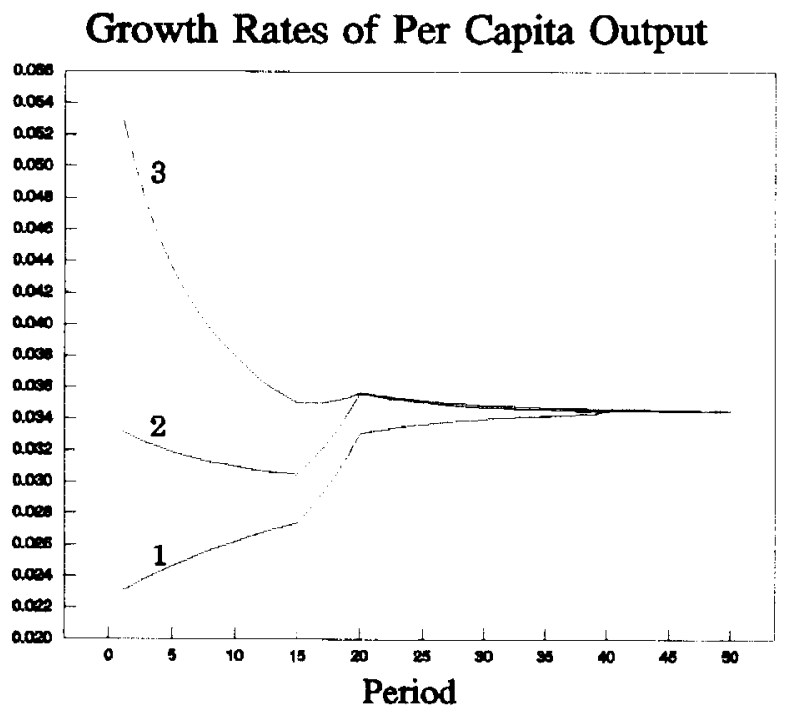

Panel D

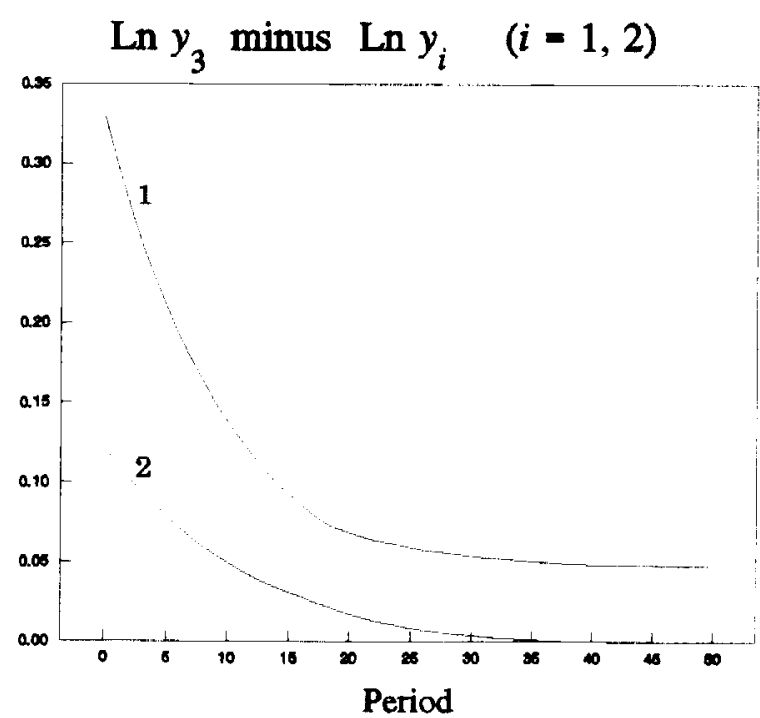


Figure 3

Panel A:

EEC Trade Liberalization:

Trade Volumes and Income Convergence

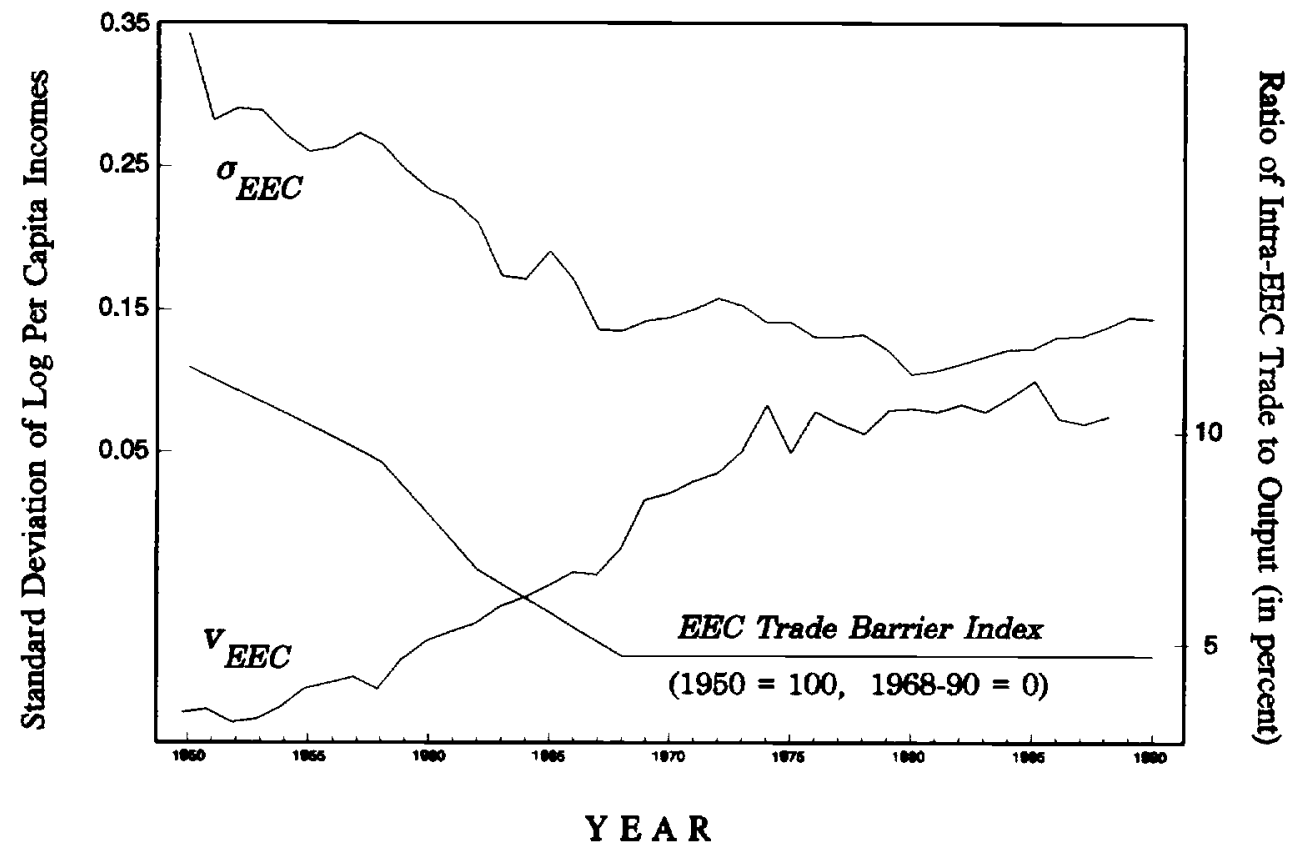

Panel B: Long-Run Income Disparity Among Future EEC Founders

(Belgium, France, Italy, Germany, and the Netherlands)

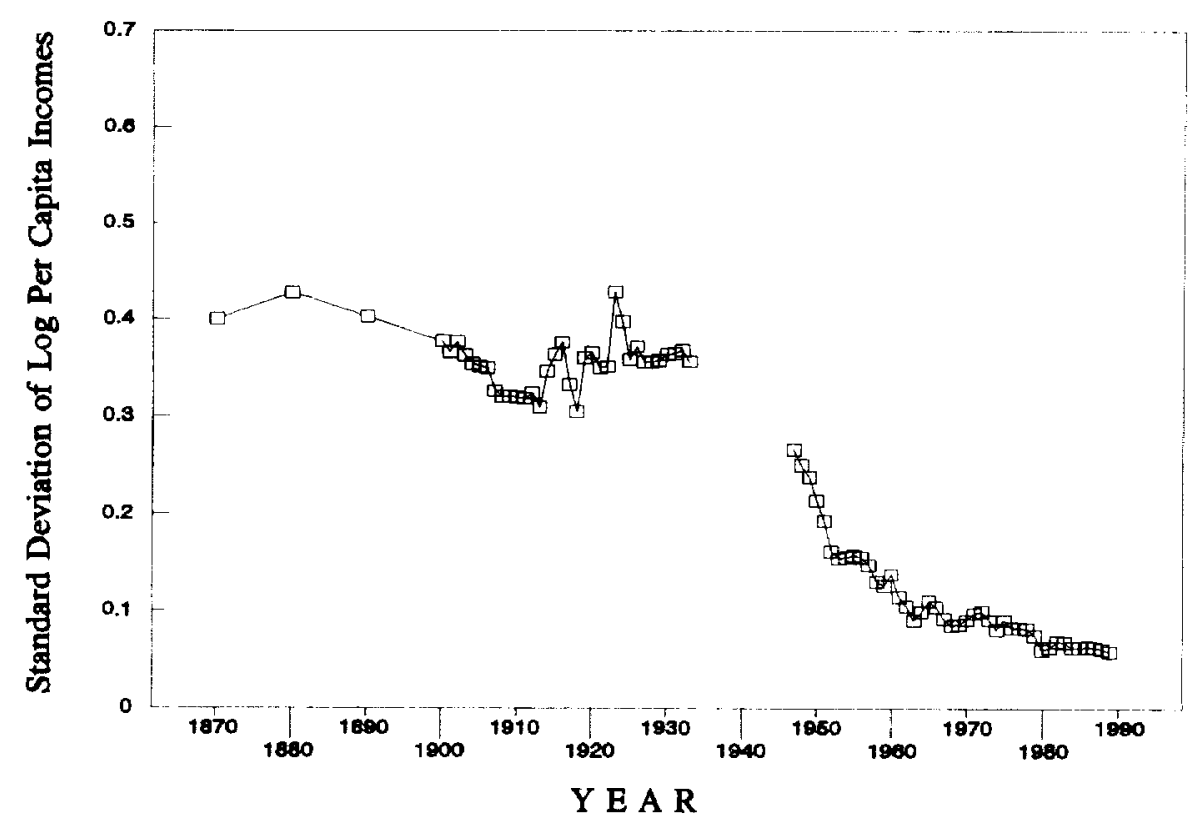




\section{Figure 4: Comparisons of 1940-89 Growth Paths}

With 1870-1939 Paths
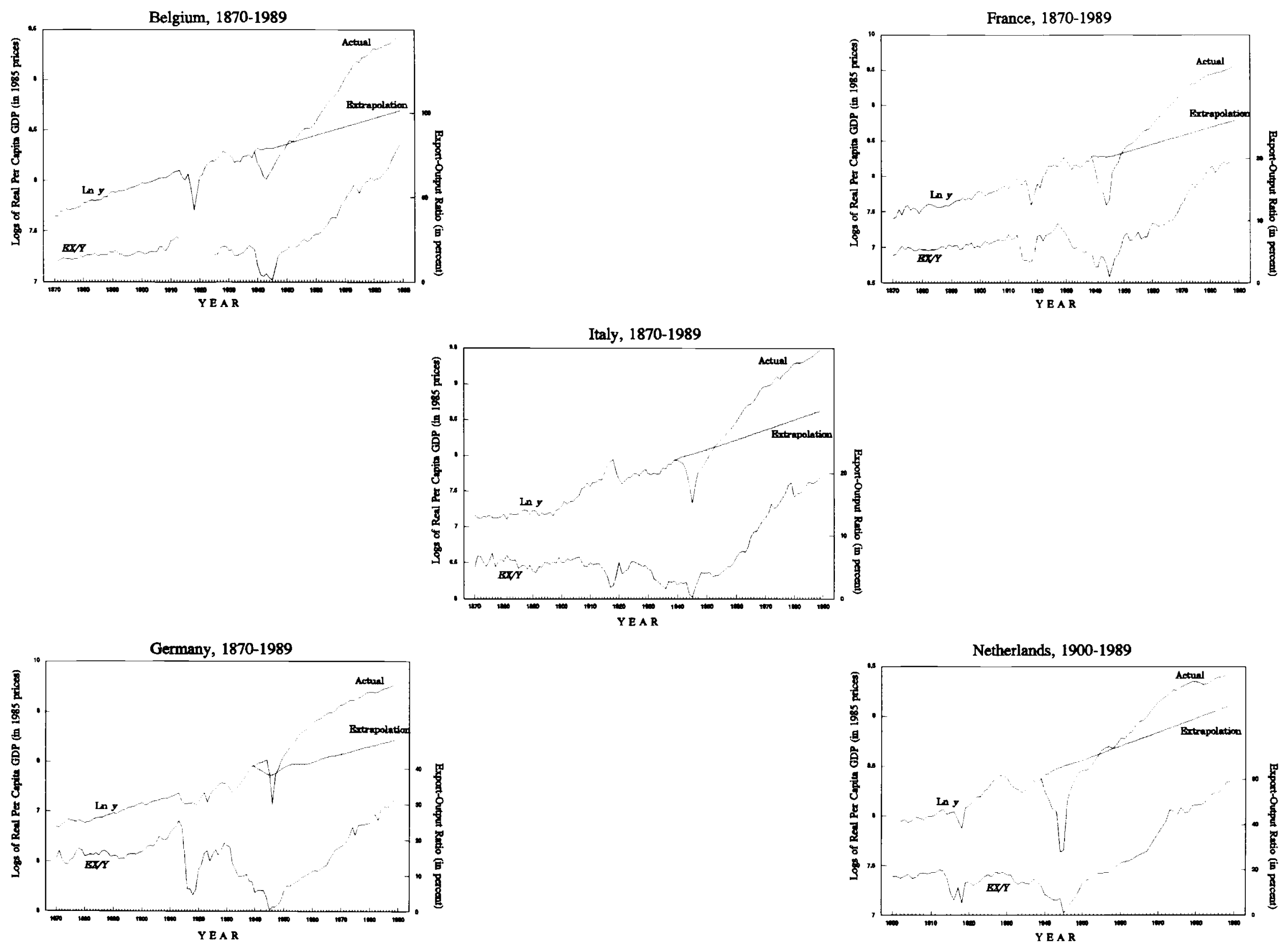